\title{
Influence of the use of wastewater on nutrient absorption and production of lettuce grown in a hydroponic system
}

\author{
Renata da Silva Cuba Carvalho ${ }^{\mathrm{a}, 1}$, Reinaldo Gaspar Bastos ${ }^{\mathrm{b}}$, Claudinei Fonseca Souza ${ }^{\mathrm{a}, *}$ \\ a Departamento de Recursos Ambientais e Proteção Ambiental, Centro de Ciências Agrárias, Universidade Federal de São Carlos, P.O. Box 153, Araras, SP, Brazil \\ b Departamento de Tecnologia Agroindustrial e Sócio Economia Rural, Centro de Ciências Agrárias, Universidade Federal de São Carlos. P.O. Box 153, Araras, SP, Brazil
}

\section{A R T I C L E I N F O}

\section{Keywords:}

Lactuca sativa L.

Mineral nutrition

Domestic effluent

\begin{abstract}
A B S T R A C T
The aim of this research was to evaluate the nutrient absorption and the fresh mass of lettuce plants cultivated using domestic wastewater in a hydroponic system during winter and summer seasons. The hydroponic system used was the Nutrient Film Technique with three treatments: 1) drinking water and chemical fertilizers (T1): 2) wastewater supplemented with chemical fertilizers (T2): and 3) only wastewater (T3) in a completely randomized experimental design with four replicates. The wastewater was previously characterized before being used in the treatments in order to quantify the need for nutrient supplementation in the T2 treatment. To determine the fresh mass, dry mass and nutrient absorption, three whole plant samples of each plot were collected at 1,7 , 14 and 21 days after transplanting. The nutrient absorption occurred according to a growing polynomial function for all treatments and most of the elements throughout the two cycles of the crop, except for potassium and magnesium in the T3 treatment in the winter crop. The results of fresh mass of the plant, $\mathrm{pH}$ and electrical conductivity of nutrient solutions were submitted to 2-way ANOVA, considering winter and summer as the first factor and treatments as the second one. A significant interaction between the factors for fresh mass and electrical conductivity was observed, and for that reason the average were submitted to Tukey test ( $\mathrm{p}<0.05 \%)$. For T1 and T2 treatments, significant differences were found between the average of the fresh mass of winter and summer, with higher values in winter. For the T3 treatment, no difference was found between the evaluated periods, but there was a significant difference in relation to the other treatments in both periods. The plants of this last treatment had lower fresh mass, less accumulation of nutrients and visual symptoms of nutritional deficiency. Under the experimental conditions, it was concluded that there was no difference in the nutrient absorption between the T1 and T2 treatment, but in the T3 treatment, the absorption was slower and smaller, demonstrating that it is necessary to supplement the wastewater with nutrients.
\end{abstract}

\section{Introduction}

The interest in wastewater use in agriculture has been increasing since it represents an alternative source of water and nutrients for plant crops. In several developed and developing countries domestic wastewater has been used in agriculture (Rana et al., 2011; Roosta and Hamidpour, 2013). In addition to water reuse, the search for production systems that provide the most efficient use of water in agriculture has also increased.

Hydroponics, defined as the technique of plant cultivation without soil using only water and dissolved nutrients, presents many advantages, including faster growth, high productivity, easy handling, and greater efficiency in water use (dos Santos et al., 2013). According to Rana et al. (2011) this type of cultivation was developed to increase food production, but emphasized that the technique can also be used for effluent treatment. The same authors report that several vegetables and economically important flowers are able to use nitrogen and phosphorus for their growth from nutrient rich wastewater.

According to Paulus et al. (2012), for hydroponic lettuce (Lactuca sativa L.) cultivation, it is possible to use nutrient solutions prepared with low quality water, or reuse nutrient solutions. The use of alternative sources of water and fertilizers may represent a reduction in production costs in the hydroponic system (Azad et al., 2013), but there is a lack of information on the correct management of the nutrient solution (Bugbee, 2004). Although effluents contain macro and micronutrients, the contents found may be limiting to the growth of plants, either by excess or nutrient deficiency (Almuktar et al., 2015).

The characterization of the wastewater is essential for its use in

\footnotetext{
* Corresponding author.

E-mail address: cfsouza@ufscar.br (C.F. Souza).

${ }^{1}$ Present address: Faculty of Agronomic Sciences, Universidade Estadual Paulista - UNESP, P.O. Box 237, Botucatu, SP, Brazil.
} 
hydroponic crops. However, knowledge of the amount of nutrients accumulated in a plant cultivated with wastewater at each stage of development can provide important information about the actual availability of these nutrients and possible handling of the nutrient solution.

Therefore, this study evaluated the performance of a hydroponic lettuce culture of curly variety with domestic wastewater during the winter and summer periods regarding the absorption and accumulation of nutrients in the plants along the growing cycle, as well as its influence on production.

\section{Materials and methods}

The cultivation was carried out at the installations of the Department of Natural Resources and Environmental Protection (DRNPA) in Federal University of Sao Carlos (UFSCar) in the city of Araras, State of Sao Paulo, Brazil (latitude $22^{\circ} 18^{\prime} 22.4^{\prime \prime} \mathrm{S}$ and longitude of $47^{\circ} 23^{\prime} 11.1^{\prime \prime} \mathrm{W}$ ). The study was conducted in a greenhouse, composed of a metal structure of the type in arch, covered with transparent polyethylene, with a height of $3 \mathrm{~m}$ and a dimension of $20 \mathrm{~m}$ of length by $6.40 \mathrm{~m}$ of width, with sides closed by sombrite type. The temperature and relative humidity of the internal and external air to the greenhouse were monitored throughout the experimental period, and the average results are shown in Fig. 1.

The cultivar selected was the "Vanda," which is the curly segment type that predominates in the Brazilian market. The hydroponic system adopted was the Laminar Nutrient Flow Technique (NFT) (Azad et al.,
Table 1

Nutrition solution proposed by Martinez and Silva Filho (2004) for the cultivation of lettuce.

\begin{tabular}{lll}
\hline Fertilizer & Chemical Formula & Concentration $\left(\mathrm{g} \mathrm{m}^{-3}\right)$ \\
\hline Calcium nitrate & $\mathrm{Ca}\left(\mathrm{NO}_{3}\right) 2.4 \mathrm{H}_{2} \mathrm{O}$ & 900 \\
Potassium nitrate & $\mathrm{KNO}_{3}$ & 134 \\
Potassium sulphate & $\mathrm{K}_{2} \mathrm{SO}_{4}$ & 280 \\
Magnesium sulphate & $\mathrm{MgSO}_{4} \cdot 7 \mathrm{H}_{2} \mathrm{O}$ & 495 \\
Potassium chloride & $\mathrm{KCl}$ & 138 \\
Monoammonium phosphate & $\mathrm{NH}_{4} \mathrm{H}_{2} \mathrm{PO}_{4}$ & 142 \\
Ferric chloride & $\mathrm{FeCl}_{3} \cdot 6 \mathrm{H}_{2} \mathrm{O}$ & 11.97 \\
Manganese sulphate & $\mathrm{MnSO}_{4} \cdot \mathrm{H}_{2} \mathrm{O}$ & 3.39 \\
Boric acid & $\mathrm{H}_{3} \mathrm{BO}_{3}$ & 2.92 \\
Zinc sulphate & $\mathrm{ZnSO}_{4} \cdot 7 \mathrm{H}_{2} \mathrm{O}$ & 0.49 \\
Copper sulphate & $\mathrm{CuSO}_{4} \cdot 5 \mathrm{H}_{2} \mathrm{O}$ & 0.08 \\
Sodium molybdate & $\mathrm{Na}_{2} \mathrm{MoO}_{4} \cdot 2 \mathrm{H}_{2} \mathrm{O}$ & 0.12 \\
EDTA-disodium & $\mathrm{C}_{10} \mathrm{H}_{14} \mathrm{~N}_{2} \mathrm{O}_{8} \mathrm{Na}_{2} \cdot 2 \mathrm{H}_{2} \mathrm{O}$ & 16.42 \\
\hline
\end{tabular}

2013). The lettuce seedlings were transplanted to a nursery where they remained for 14 days until they reached the ideal size to be transferred to the defined location of the experiment. The defined growing periods were from November 24th to December 14th, 2014 (summer) and from August 1st to 23rd, 2015 (winter). In the nursery the plants were grown in nutrient solution as proposed by Martinez and Silva Filho (2004) (Table 1).

The cultivation environment was composed of twelve workbenches (plots), each three meters in length, and with four polypropylene hydroponic profiles $(75 \mathrm{~mm})$ per workbench, in a greenhouse. The
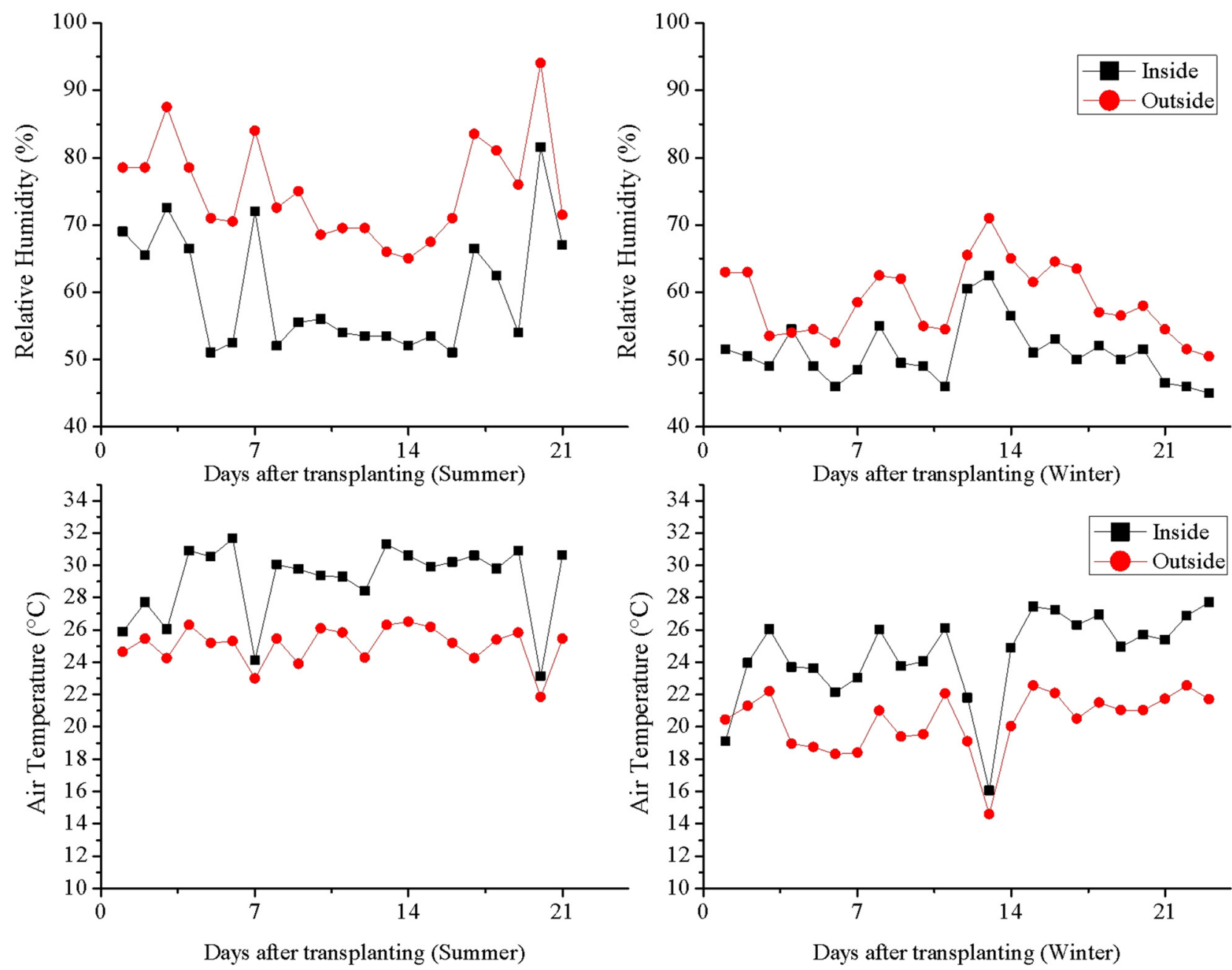

Fig. 1. Average values the relative humidity and air temperature monitored inside and outside the greenhouse, during the two crops (winter and summer). 


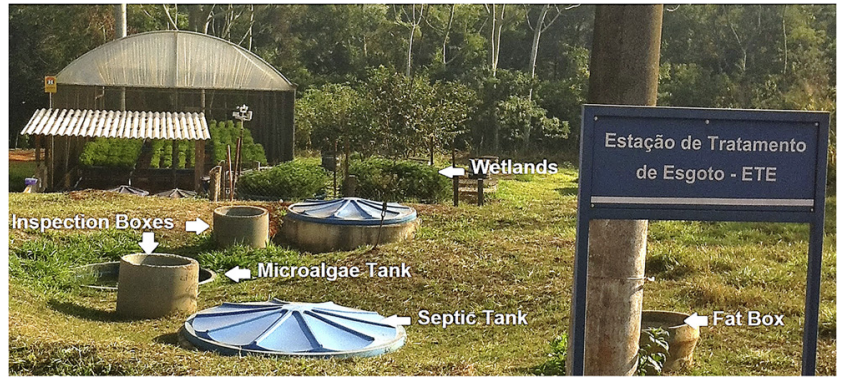

Fig. 2. Sewage Treatment Station (STS) and greenhouse.

experimental plan used was completely randomized, with three treatments and four replications, totaling twelve plots for each period, winter and summer. The first treatment was fed with drinking water supply and chemical fertilizers (T1), the second with wastewater and supplemented with chemical fertilizers according to the results of the water's chemical analyzes (T2) and the third with only wastewater (T3) of which were also made chemical analyzes.

The structure of each treatment was composed of an NFT hydroponic system, containing a tank with a capacity to store $500 \mathrm{~L}$ of nutrient solution, a pumping system, four benches (repetitions) with four hydroponic profiles and a solution return system to the tank. The spacing used was $0.25 \mathrm{~m}$ between plants in the hydroponic profiles and $0.30 \mathrm{~m}$ between plants of the different profiles; in this way there were 12 plants per profile, 48 per bench and 192 plants by treatment. The slope was $10 \%$ to facilitate nutrient solution flow by gravity, which maintained $1.5 \mathrm{~L} \mathrm{~min}^{-1}$ for each profile.

The wastewater used was collected at the exit of a sewage treatment station (STS), which is installed at the front of the greenhouse (Fig. 2). This station treats sewage from the toilets and the university restaurant and was monitored for a year by Souza et al. (2015). The station is divided into several units (Fig. 3), where the raw effluent that is generated is first discharged into a septic tank, followed by PVC piping to a microalgae pond, then to a wetlands tank and finally to an equalization tank where it is stored for use.

The wastewater analysis was done weekly before its nutritional adjustment (Table 2) from $0.5 \mathrm{~L}$ equalizer tank samples in a sterile bottle and was conducted at the Laboratory of Soil Pollution for analysis of its physical and chemical parameters, such as $\mathrm{pH}$, turbidity, biochemical oxygen demand $\left(\mathrm{BOD}_{5}{ }^{20}\right)$, dissolved oxygen (DO), electrical conductivity (EC), total phosphorus (TP) and total nitrogen (TN). Other chemical parameters, such as calcium $(\mathrm{Ca})$, potassium $(\mathrm{K})$, magnesium $(\mathrm{Mg})$, sulfur (S) and sodium ( $\mathrm{Na})$, were analyzed at the Laboratory of Soil Fertility. The analytical methodology adopted in all analyses of the wastewater (chemical and physical), is in agreement with Standard Methods for the Examination of Water and Wastewater (APHA, 2012).

The preparation of the nutrient solution for T1 and T2 was completed based on the recommendation for the lettuce crop proposed by Martinez and Silva Filho (2004) (Table 1). In the T2 treatment, the
Table 2

Average results of the physical-chemical characterization of the wastewater used in both crops.

\begin{tabular}{|c|c|c|c|c|}
\hline \multirow[t]{2}{*}{ Parameters } & \multicolumn{2}{|c|}{ Summer Growth } & \multicolumn{2}{|c|}{ Winter Growth } \\
\hline & Average & Standard Deviation & Average & Standard Deviation \\
\hline $\mathrm{pH}$ & 8.03 & 0.06 & 7.38 & 0.15 \\
\hline $\mathrm{EC}\left(\mathrm{dS} \mathrm{m} \mathrm{m}^{-1}\right)$ & 0.86 & 0.23 & 0.72 & 0.12 \\
\hline $\mathrm{BOD}_{5}{ }^{20}\left(\mathrm{mg} \mathrm{L}^{-1}\right)$ & 38.63 & 3.33 & 42.30 & 9.84 \\
\hline $\mathrm{DO}\left(\mathrm{mg} \mathrm{L}^{-1}\right)$ & 2.41 & 0.66 & 2.35 & 0.27 \\
\hline Turbidity (NTU) & 17.76 & 9.01 & 21.35 & 4.45 \\
\hline $\mathrm{NT}\left(\mathrm{mg} \mathrm{L}^{-1}\right)$ & 44.74 & 5.12 & 23.80 & 6.08 \\
\hline $\mathrm{TP}\left(\mathrm{mg} \mathrm{L}^{-1}\right)$ & 15.33 & 0.67 & 5.08 & 2.55 \\
\hline $\mathrm{K}\left(\mathrm{mg} \mathrm{L}^{-1}\right)$ & 18.83 & 2.75 & 14.50 & 7.19 \\
\hline $\mathrm{Ca}\left(\mathrm{mg} \mathrm{L}^{-1}\right)$ & 38.67 & 7.51 & 48.39 & 17.37 \\
\hline $\mathrm{Mg}\left(\mathrm{mg} \mathrm{L}^{-1}\right)$ & 10.93 & 2.01 & 11.39 & 9.53 \\
\hline $\mathrm{S}\left(\mathrm{mg} \mathrm{L}^{-1}\right)$ & 101.33 & 22.14 & 28.89 & 37.53 \\
\hline $\mathrm{Na}\left(\mathrm{mg} \mathrm{L}^{-1}\right)$ & 87.91 & 80.32 & 53.00 & 40.27 \\
\hline
\end{tabular}

EC: electrical conductivity; $\mathrm{BOD}_{5}{ }^{20}$ : biochemical oxygen demand; DO: dissolved oxygen; TN: total nitrogen; TP: total phosphorus; K: potassium; Ca: calcium; Mg: magnesium; S: sulfur; Na: sodium.

addition of the fertilizers was carried out by discounting the contents already present in the treated effluent, and for treatment T3, as has already been mentioned, the solution used was only wastewater.

To maintain a favorable environment for the development of the plants in this system, it was important to monitor daily $\mathrm{pH}$ and electrical conductivity of the solutions, through which it was possible to determine the necessity of adding salts to adjust the electrical conductivity (Azad et al., 2013). The replacement of water in the reservoirs of each treatment was carried out weekly, and from the volume added and the reading of the electrical conductivity the mineral fertilizers were added.

In order to evaluate the nutritional status of the culture, at $2 / 3$ of the development (15 DAT), 15 newly developed leaves of each of the treatments were randomly collected, following the methodology proposed by Raij et al. (1997), to determine the leaf contents of nitrogen $(\mathrm{N})$, phosphorus $(\mathrm{P})$, potassium $(\mathrm{K})$, calcium $(\mathrm{Ca})$, magnesium $(\mathrm{Mg})$, sulfur (S), boron (B), copper ( $\mathrm{Cu})$, iron (Fe), manganese (Mn) and zinc (Zn).

Quantification of the fresh mass was performed through the collection of whole plants, leaves and roots, at 1, 7, 14 and 21 DAT. The number of plants per plot (workbench) were 48 and 3 plants were collected at each sampling date, this way, the number remaining for the final analysis at harvest were 36 plants per plot. After weighing, these plants were sent to the laboratory to determine the dry mass and the absorption in the whole plants of nitrogen $(\mathrm{N})$, phosphorus $(\mathrm{P})$, potassium $(\mathrm{K})$, calcium $(\mathrm{Ca})$ and magnesium $(\mathrm{Mg})$, sulfur $(\mathrm{S})$, iron (Fe), manganese $(\mathrm{Mn})$ and zinc $(\mathrm{Zn})$, following the methodology of plant tissue analysis described by Nogueira and Souza (2005).

In order to evaluate the effect of the interaction of the different cultivation periods (winter and summer) and the evaluated treatments, the results of the fresh mass of the plants, the electrical conductivity

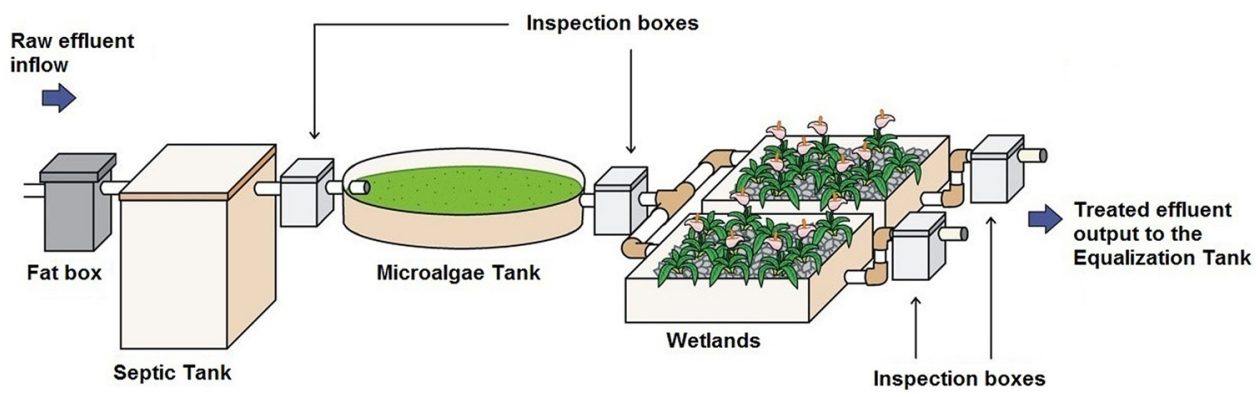

Fig. 3. Schematic representation of sewage treatment station built at Federal University of Sao Carlos (UFSCar).

Source: Adapted from Souza et al. (2015) 
and the $\mathrm{pH}$ of the different nutrient solutions were submitted to twoway analysis of variance ( $F$ test) and the average was compared by the Tukey test with $5 \%$ probability using the R CORE TEAM software.

The data used to compose the nutrient accumulation curves and dry mass were submitted to regression analysis, being considered to be independent variable the age of the plant, expressed in days, after transplanting. A polynomial or linear fitting was used for each situation.

\section{Results and discussion}

\subsection{Water quality for hydroponics}

The results of the characterization of the wastewater, as previously described (Table 1), are mainly related to the origin of the domestic effluent, and also to the treatment process used. Souza et al. (2015) monitored this Sewage Treatment Station (STS) with the objective of evaluating the efficiency of the treatment system and the possibility of applying the wastewater in agriculture, and concluded that the wastewater is suitable for use in agriculture, but the application should be localized, and if applied to the soil, it should be monitored to avoid the risk of salinization due to the high concentrations of sodium found in the effluent.

The great variation found in the content's results of total nitrogen, sulfur and total phosphorus of the wastewater in winter and summer is due to the seasonality of the STS operation, since the treated effluent comes from the university which, during the period of July, its generation is greatly reduced, increasing the hydraulic retention time by changing the characteristics of the wastewater.

In the literature are found parameters on the quality of wastewater for application in the soil (WHO, 2006), therefore, there is no specific recommendation for hydroponic cultures. The results of the characterization of the wastewater were compared with the water quality recommendations for hydroponics described by Böhme, (1993), being the average values of electrical conductivity and $\mathrm{pH}$ considered acceptable. For sodium, according to the same author, values up to $87 \mathrm{mg} \mathrm{L}^{-1}$, the water is indicated as good to be used in hydroponics.

The cultivation of lettuce for soil cultivation is classified as moderately sensitive to salinity (Ayers and Westcot, 1999), and in hydroponic cultivation it is considered tolerant, according to Resh (1995). This difference is due to the low or no matric potential on the total water potential, allowing greater absorption of water and nutrients in plants grown in the most diverse types of hydroponics, besides providing greater tolerance to salinity in relation to conventional soil cultivation (Soares et al., 2007).

When comparing the mean values of total nitrogen, total phosphorus, potassium, calcium, magnesium and sulfur present in the wastewater with the values proposed by Martinez and Silva Filho (2004) (Table 2) for hydroponic cultivation, these are insufficient to be used as nutritious solution for the lettuce culture, and a nutrient supply is necessary. Lettuce plants can extract approximately $77 \%$ of the phosphorus and $80 \%$ of the nitrogen contained in the wastewater solution from sanitary sewage (Boyden and Rababah, 1996), but they present a reduction of more than $50 \%$ in their fresh mass (Cuba et al., 2015; Boyden and Rababah, 1996), with the inadequate concentration of nutrients in wastewater being the main factor.

\subsection{Absorption of nutrients and growth of lettuces}

The nutrient foliar contents of both cultures (Table 3) were compared with the recommended range for the culture according to Raij et al. (1997). For the T1 treatment in the summer culture, the contents of potassium and calcium were below the range recommended for the culture, whereas in the treatment T2 it was potassium and magnesium which were below recommended levels, however the plants did not present any visual symptom of these deficiencies.
In winter culture for treatments $\mathrm{T} 1$ and $\mathrm{T} 2$ calcium and magnesium were below the adequate range, but without visual deficiency symptoms. For the other macronutrients and micronutrients, the values were within the appropriate range.

In the $\mathrm{T} 3$ treatment, in the evaluated periods, visual symptoms of nutritional deficiency were observed five days after transplantation to the final site, and nutrient foliar contents were below for most of the nutrients, except for boron, copper and zinc. These results suggest the need to investigate the amount of micronutrients present in the wastewater, and therefore be able to interpret whether the leaf contents found were due to absorption during the period that the seedlings were pre-acclimated or if the wastewater provided some contribution.

The results of the nutrient and dry mass accumulation in the lettuce plants of the different treatments in the summer crop are presented in Figs. 4 and 5, respectively, and for the winter crop in Figs. 6 and 7, respectively. The nutrient absorption increased for most of the elements over the two crop cycles for all treatments, and statistical regression analysis presented that this accumulation in plants is significantly related to their growth. The choice of function for each nutrient was according to the behavior of each nutrient and treatment. The determination coefficients $\left(\mathrm{R}^{2}\right)$ for most macronutrients and micronutrients were higher than 0.95 , showing adequate adjustment to the chosen model.

When comparing the trend lines of the three treatments in both cultures up to 7 days, the accumulation of nutrients is very similar, but from this period in the T3 the behavior is differentiated by the weakness in the growth of the plants, whose complete reduction in the level of macronutrients in the wastewater promotes lower growth and, consequently, lower mass gain.

According to Taiz and Zeiger (2013), the elements considered essential are classified according to their relative concentrations in the plant tissue in the following growing order: $\mathrm{N}>\mathrm{K}>\mathrm{Ca}>\mathrm{Mg}>$ $\mathrm{P}>\mathrm{S}>\mathrm{Fe}>\mathrm{B}>\mathrm{Mn}>\mathrm{Zn}>\mathrm{Cu}$. In summer cultivation, the growing order of nutrients extracted from the nutrient solution for T1 was $\mathrm{K}>\mathrm{N}>\mathrm{Ca}>\mathrm{P}>\mathrm{S}>\mathrm{Mg}>\mathrm{Fe}>\mathrm{Mn}>\mathrm{Cu}>\mathrm{B}>\mathrm{Zn}$, whereas for $\mathrm{T} 2$ and $\mathrm{T} 3$ it was $\mathrm{N}>\mathrm{K}>\mathrm{Ca}>\mathrm{P}>\mathrm{S}>\mathrm{Mg}>$ $\mathrm{Fe}>\mathrm{Mn}>\mathrm{Cu}>\mathrm{B}>\mathrm{Zn}$. On the other hand, for winter cultivation the order of nutrients absorbed for $\mathrm{T} 1$ and $\mathrm{T} 2$ was $\mathrm{N}>\mathrm{K}>\mathrm{Ca}>$ $\mathrm{P}>\mathrm{S}>\mathrm{Mg}>\mathrm{Fe}>\mathrm{Mn}>\mathrm{Zn}>\mathrm{Cu}>\mathrm{B}$, and for $\mathrm{T} 3$ it was $\mathrm{N}>\mathrm{K}>\mathrm{Ca}>\mathrm{P}>\mathrm{Mg}>\mathrm{S}>\mathrm{Fe}>\mathrm{Mn}>\mathrm{Zn}>\mathrm{Cu}>\mathrm{B}$. According to Epstein and Bloom (2004), the nutriment concentration and proportion may vary in different plants and growing conditions. For dry weight, for example, the expected levels of N, K, and Ca are of $0.5-6 \%$, $0.8-8 \%$, and $0.1-6 \%$, respectively. The accumulated amount of nutriments between the treatments and the growing seasons, as nitrogen, potassium, and calcium are the elements at higher concentration in the crop at each treatment.

The lettuce culture, because it is composed mainly of leaves, responds adequately to the nitrogen supply. The highest values of this element accumulated in the plants were in the summer crop for the treatments $\mathrm{T} 1$ and $\mathrm{T} 2$, being 0.98 and $0.94 \mathrm{~g} \mathrm{plant}^{-1}$, respectively, at 21 DAT. When evaluating the absorption curve along the growth cycle, up to 7 days after transplanting, it was noted that during this period there is more intense growth and consequently a higher concentration of nutrients. In the treatments $\mathrm{T} 1$ and $\mathrm{T} 2$ up to 7 days there was an accumulation of $20 \%$ of the maximum absorbed $\mathrm{N}$, and in the $\mathrm{T} 3$ treatment this value was $45 \%$.

In winter, the maximum nitrogen accumulation at 21 DAT was lower in all treatments when compared with the summer results, being 0.46; 0.60 and $0.16 \mathrm{~g}_{\text {plant }^{-1}}$ for $\mathrm{T} 1, \mathrm{~T} 2$ and $\mathrm{T} 3$, respectively. The T3 treatment at 7 DAT already had $67 \%$ of the total $\mathrm{N}$ accumulated, and the other treatments approximately $24 \%$ of the total. Nitrogen is the element most required by most crops (Bugbee, 2004), and because it's part of chlorophyll molecules, when its content is insufficient, the result is a reduction in the rate of photosynthesis. The T3 treatment plants at 5 DAT already had symptoms of nitrogen deficiency. 
Table 3

Foliar contents of nutrients at 15 days after transplanting and recommended range for the crop as proposed by Raij et al. (1997).

\begin{tabular}{|c|c|c|c|c|c|c|c|c|c|c|c|c|}
\hline \multicolumn{2}{|c|}{ Treatments } & \multicolumn{6}{|c|}{ Macronutrients $\mathrm{g} \mathrm{kg}^{-1}$} & \multicolumn{5}{|c|}{ Micronutrients $\mathrm{mg} \mathrm{kg}^{-1}$} \\
\hline & & $\mathrm{N}$ & $\mathrm{P}$ & $\mathrm{K}$ & $\mathrm{Ca}$ & $\mathrm{Mg}$ & $\mathrm{S}$ & $\mathrm{B}$ & $\mathrm{Cu}$ & $\mathrm{Fe}$ & Mn & $\mathrm{Zn}$ \\
\hline \multirow[t]{3}{*}{ Summer } & $\mathrm{T} 1$ & 45.0 & 5.6 & 41.5 & 14.5 & 4.7 & 5.4 & 43 & 31 & 164 & 198 & 30 \\
\hline & $\mathrm{T} 2$ & 43.0 & 6.8 & 44.0 & 20.4 & 3.8 & 4.9 & 60 & 53 & 256 & 313 & 48 \\
\hline & $\mathrm{T} 3$ & 26.0 & 2.6 & 11.1 & 11.4 & 1.1 & 0.7 & 35 & 17 & 166 & 204 & 50 \\
\hline \multirow[t]{3}{*}{ Winter } & $\mathrm{T} 1$ & 48.5 & 7.6 & 54.3 & 10.2 & 3.1 & 3.1 & 4 & 17 & 283 & 238 & 80 \\
\hline & $\mathrm{T} 2$ & 49.5 & 7.9 & 49.2 & 10.8 & 2.9 & 2.8 & 10 & 16 & 214 & 255 & 47 \\
\hline & $\mathrm{T} 3$ & 27.5 & 3.4 & 8.4 & 6.8 & 2.1 & 1.3 & 8 & 11 & 181 & 118 & 26 \\
\hline \multicolumn{2}{|c|}{ Raij et al. (1997) } & $30-50$ & $04-07$ & $50-80$ & $15-25$ & 04-06 & $1.5-2.5$ & $30-60$ & $07-20$ & $50-250$ & $30-150$ & $30-100$ \\
\hline
\end{tabular}
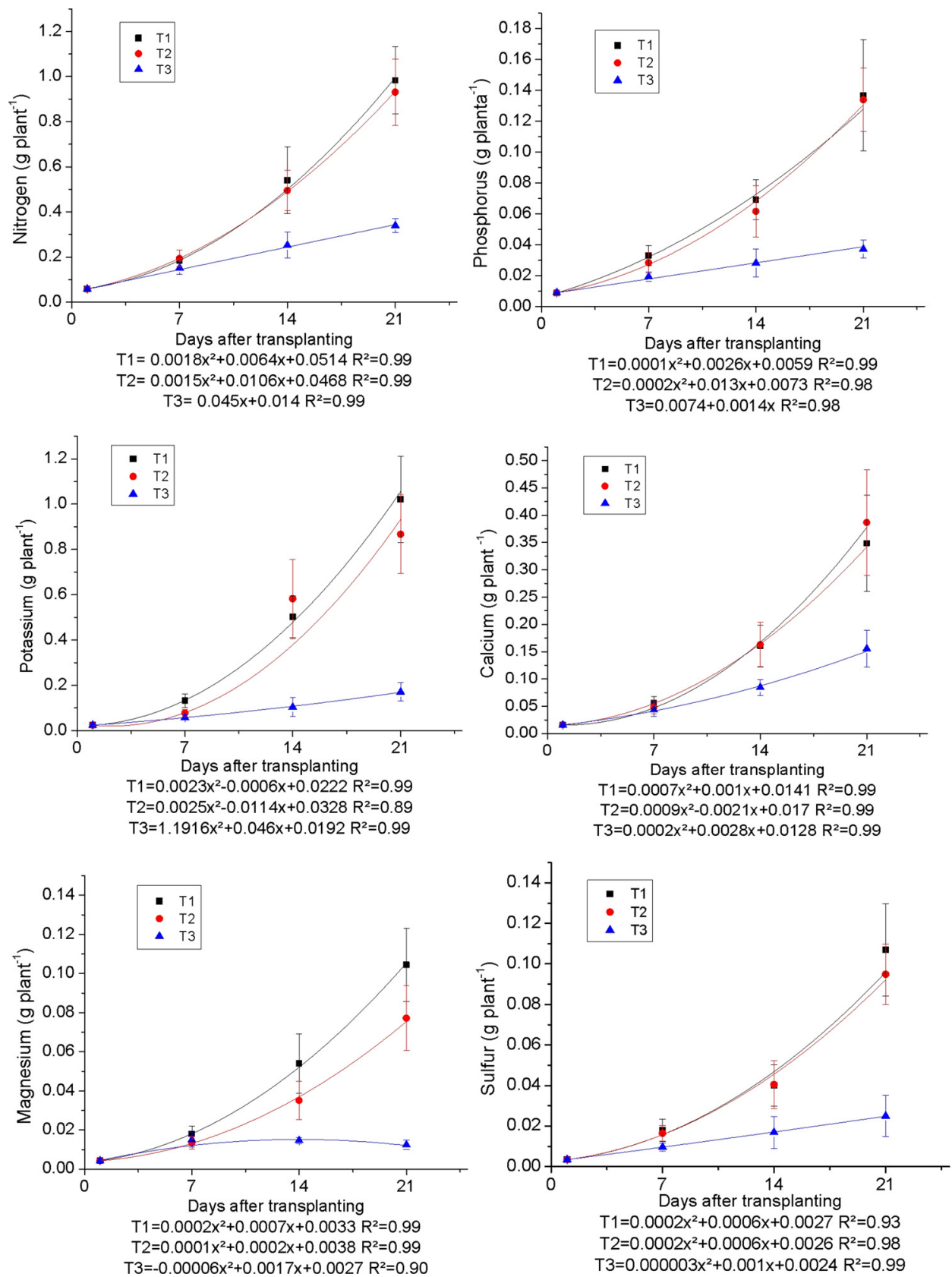

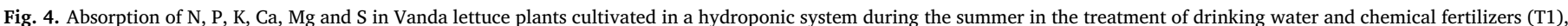
wastewater and supplemented with chemical fertilizers (T2) and wastewater only (T3) at 1, 7, 14 and 21 days after transplanting. 

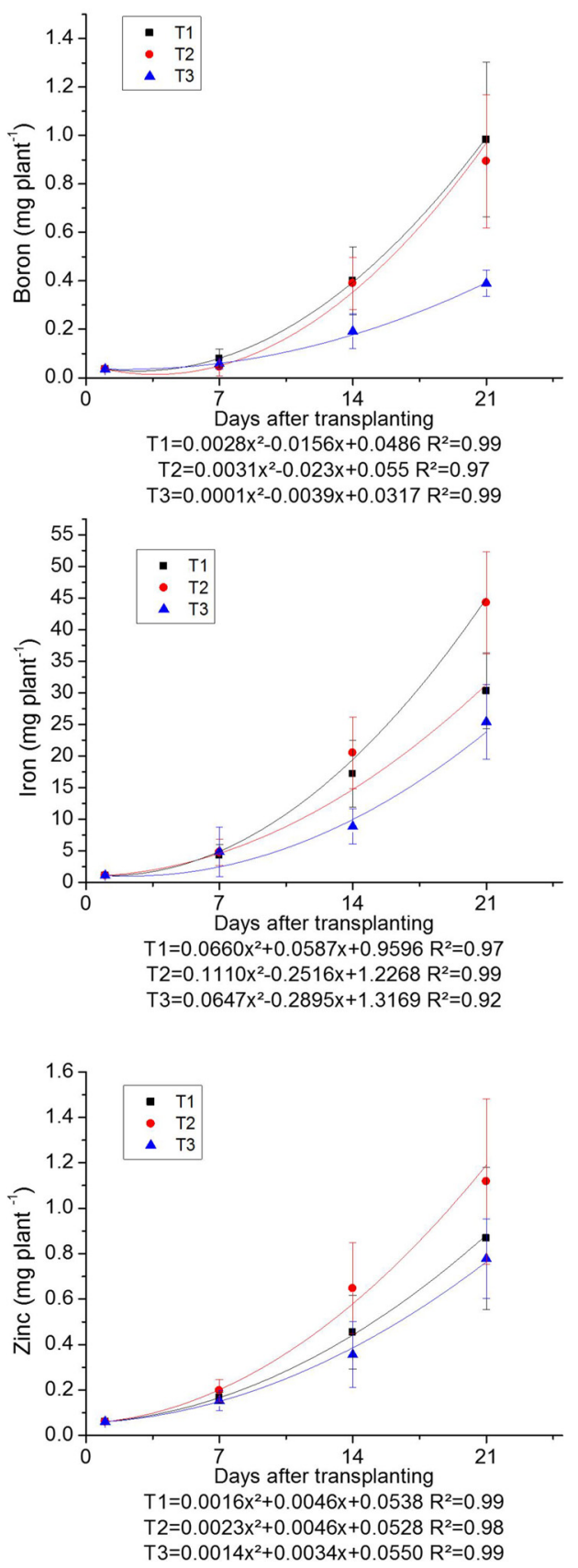
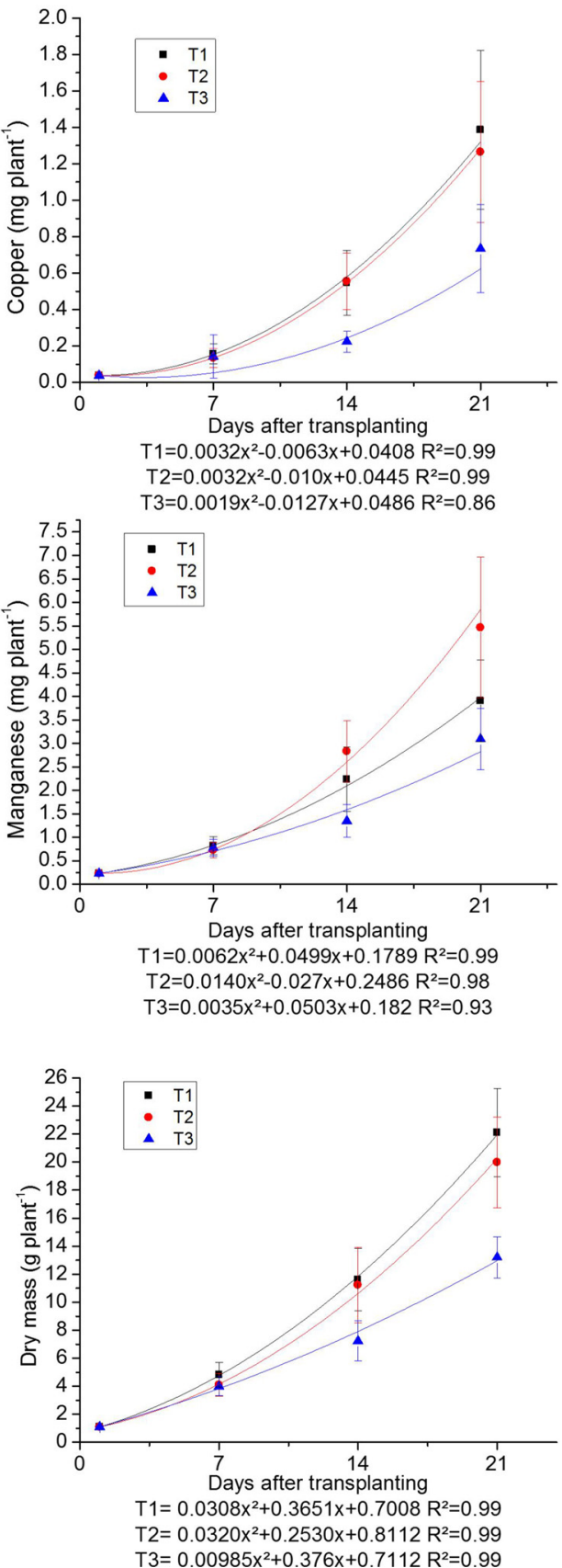

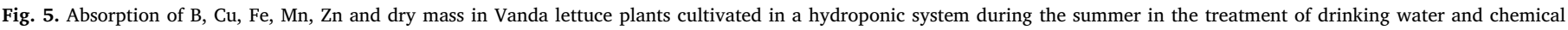
fertilizers (T1), wastewater and supplemented with chemical fertilizers (T2) and wastewater only (T3) at 1, 7, 14 and 21 days after transplanting.

According to Grangeiro et al. (2006), Lopes et al. (2003) and Martins et al. (2009), lettuce cultivation presents a higher demand for potassium in comparison to other nutrients from $12 \mathrm{DAT}$, either in the soil or in the NFT hydroponic system. In this study, the maximum values of $\mathrm{K}$ in the plants were $1.02 \mathrm{~g}$ plant $^{-1}$ for the T1 and $0.86 \mathrm{~g} \mathrm{plant}^{-1}$ for the T2 in the summer, and in the winter period the accumulation at the end of the cycle was 0.46 and $0.45 \mathrm{~g} \mathrm{plant}^{-1}$ for $\mathrm{T} 1$ and $\mathrm{T} 2$, respectively.

For the T3 treatment in summer, there was a $\mathrm{K}$ accumulation of $0.17 \mathrm{~g}$ plant $^{-1}$ at $21 \mathrm{DAT}$, and at 7 DAT the plants had accumulated approximately $33 \%$ of the maximum $\mathrm{K}$ absorbed, whereas in winter the highest accumulation observed was $0.10 \mathrm{~g} \mathrm{plant}^{-1}$ at $7 \mathrm{DAT}$, and at 21 DAT there was a decrease of $42 \%$ of this nutrient. Sodium in nutrient solution exerts an antagonist effect on potassium, and its presence in wastewater with a lower $\mathrm{K}$ concentration may have influenced the T3 treatment.

Also, in T3, treatment plants at the end of the two cycles, small brown staining spots on the edges of older leaves were observed, a symptom of insufficient potassium. According to Taiz and Zeiger (2013), this nutrient activates several enzymes involved in photosynthesis, influencing the productivity and final quality of the product.

From the middle of the two cycles of the T3 treatment, calcium deficiency was observed, with the appearance of necrosis in the apical meristems of the leaves, known as "tip burn" or necrosis in the root meristems. These symptoms occur because calcium plays an essential role in the meristematic growth in the leaves, but mainly in the roots.

The maximum accumulation of Ca by plants in the T3 treatment reached $0.17 \mathrm{~g} \mathrm{plant}^{-1}$ in summer and $0.04 \mathrm{~g}$ plant $^{-1}$ in winter, both at 21 DAT. In T1 and T2 treatments, the maximum values found at 21 DAT of $\mathrm{Ca}$ in the plants were 0.34 and $0.38 \mathrm{~g} \mathrm{plant}^{-1}$ in summer and 0.11 

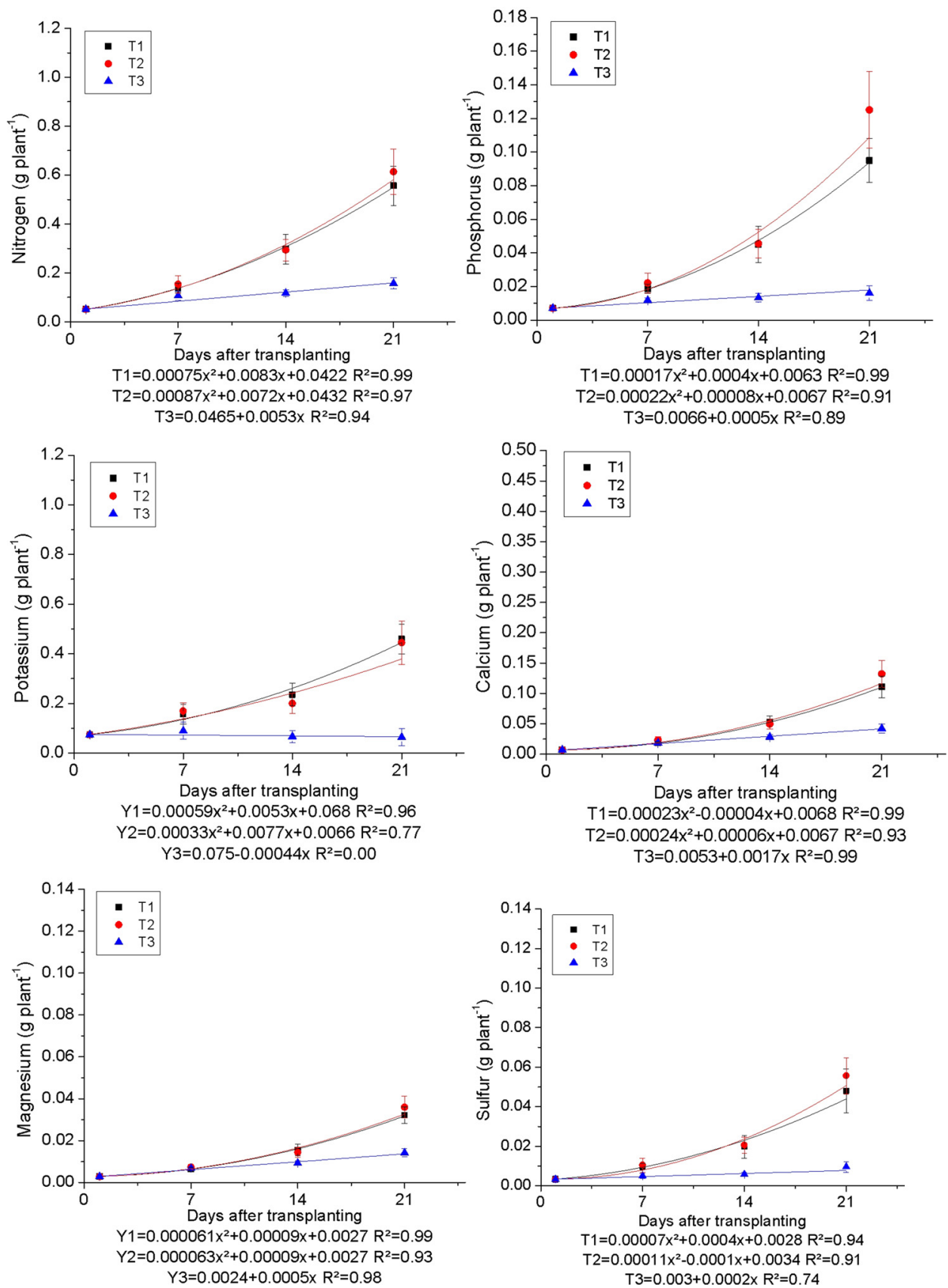

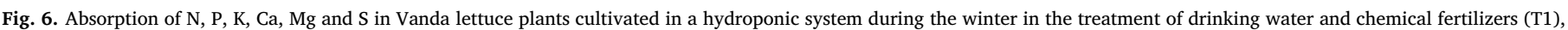
wastewater and supplemented with chemical fertilizers (T2) and wastewater only (T3) at 1, 7, 14 and 21 days after transplanting.

and $0.13 \mathrm{~g}$ plant $^{-1}$ in winter, respectively. According to Adams (1991), in situations with lower luminous intensity and lower temperatures there is less transpiration of the plants, and the Ca, for being distributed only through the xylem, has reduced leaf contents.

In contrast to nitrogen and potassium, phosphorus is required in the least amount by the crop, and up to 7 DAT the plants of the T1 and T2 treatments absorbed approximately $20 \%$ and of the T3 more than $50 \%$ of the maximum accumulated during each cycle. The mean difference between the phosphorus content at the end of each cycle of the T1 and T2 treatments was 5.5 times greater than that of the T3. Phosphorus deficiency leads to a slower development of the crop and a nutritional imbalance.

The demand for magnesium increased throughout the cycles (Figs. 4 and 6), except for the T3 treatment in the summer period, for which there was a decrease from 14 DAT. The maximum accumulations were
0.10, 0.07 and $0.01 \mathrm{~g} \mathrm{plant}^{-1}$, for $\mathrm{T} 1, \mathrm{~T} 2$ and $\mathrm{T} 3$, respectively, in the summer crop, while in winter they were $0.03,0.03$ and $0.01 \mathrm{~g} \mathrm{plant}^{-1}$, for T1, T2 and T3, respectively. According to Grangeiro et al. (2006), for the Babá Summer, Tainá and Verônica lettuce cultivars the greatest demand for magnesium occurs between 22 and 27 DAT, and these crops have a maximum accumulation of $\mathrm{Mg}$ in this period of $0.14,0.10$ and $0.11 \mathrm{~g}$ plant $^{-1}$, respectively. This difference between the results of this work in the different periods of the year and the reported literature can be attributed to the concentration of nutrients in the nutrient solution, in which fluctuations in nutrient contents are expected (Saufie et al., 2015).

The handling adopted to restore the nutrient solution of the $\mathrm{T} 1$ and $\mathrm{T} 2$ treatments exerted influence on the nutrient absorption, since this replacement was performed based on the electrical conductivity and the absorbed volume of the solution. According to Yeo et al. (2013), this 

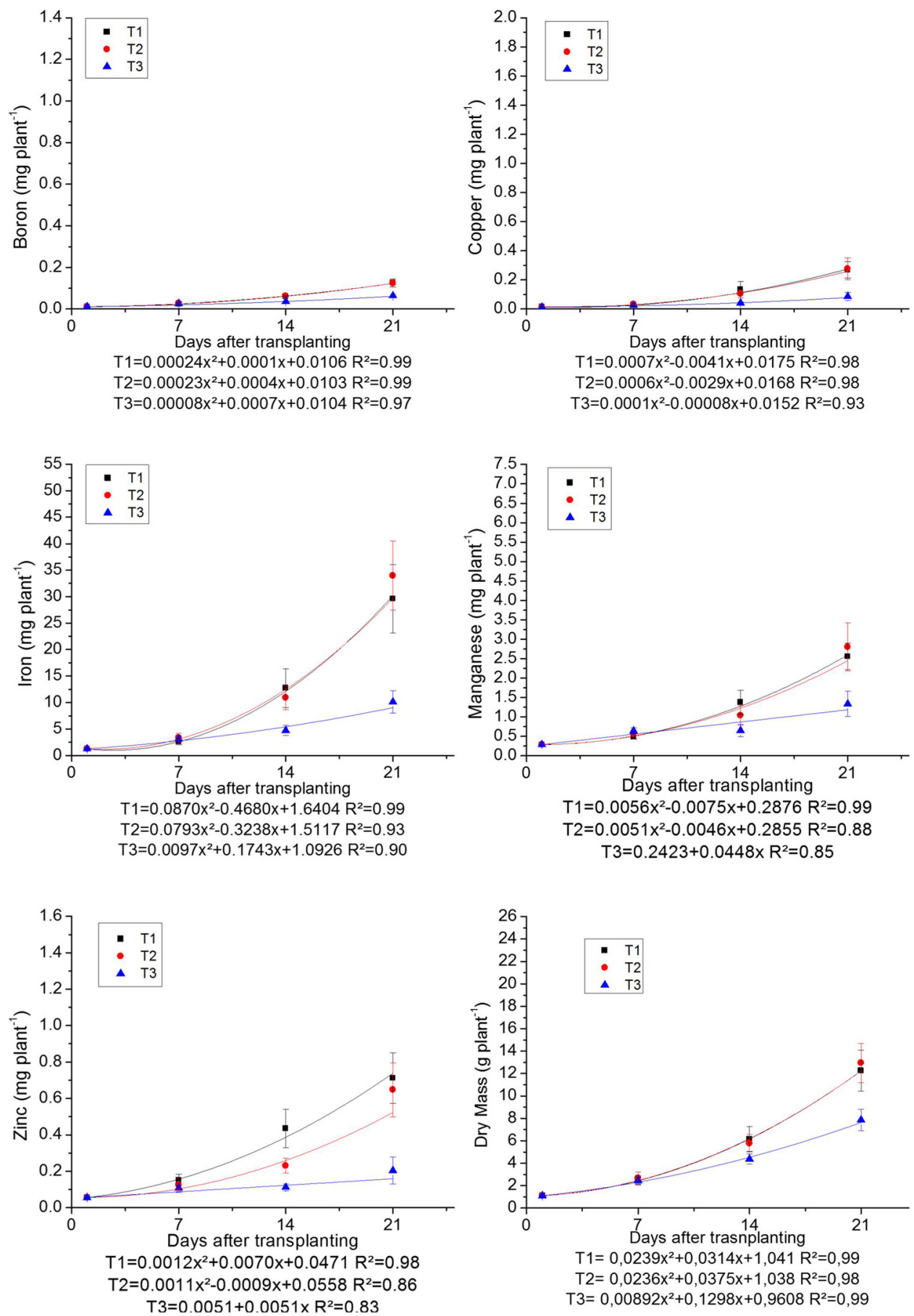

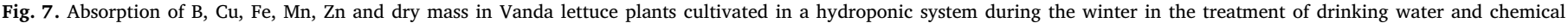
fertilizers (T1), wastewater and supplemented with chemical fertilizers (T2) and wastewater only (T3) at 1, 7, 14 and 21 days after transplanting.

practice, although very usual, does not allow the efficient diagnosis of nutrient excesses or deficiencies in the nutrient solution, which may lead to an imbalance in the nutrient solution. When measuring the electrical conductivity of a nutrient solution after circulation by plant roots, $\mathrm{Ca}, \mathrm{Mg}$ and $\mathrm{S}$, which are the elements with the lowest absorption rate, are measured mainly, in contrast to $\mathrm{N}, \mathrm{P}, \mathrm{K}$ and $\mathrm{Mn}$ (Bugbee, 2004). This practice may have provided high Ca concentrations in the medium and, thus, inhibit or decrease the rate of $\mathrm{Mg}$ uptake by the roots (Abrahão et al., 2014).

Sulfur is absorbed by plants in the form of sulfate $\left(\mathrm{SO}_{4}\right)$ and is part of carbon compounds such as amino acids, coenzymes and vitamins, which are essential to metabolism. In situations of sulfur deficiency, the symptoms are similar to the lack of nitrogen, but appear in the new leaves because it is not a movable element for most species (Taiz and Zeiger, 2013).

In winter cultivation, the maximum accumulated sulfur for both $\mathrm{T} 1$ and $\mathrm{T} 2$ treatments was $0.05 \mathrm{~g} \mathrm{plant}^{-1}$, and for T3, it was $0.01 \mathrm{~g}$ plant $^{-1}$. Gondim et al. (2010), in an experiment with the variety of lettuce BR 303 cultivated in hydroponic system, indicated sulfur was the macronutrient of least accumulation during the cultivation, having a maximum amount $0.04 \mathrm{~g}_{\text {plant }}{ }^{-1}$, which is near to the values found in winter for $\mathrm{T} 1$ and $\mathrm{T} 2$ of this work. In the summer, at $21 \mathrm{DAT}$, the sulfur contents for $\mathrm{T} 1, \mathrm{~T} 2$ and $\mathrm{T} 3$ were $0.10,0.09$ and $0.02 \mathrm{~g} \mathrm{plant}^{-1}$, respectively, the greatest demand for the first two treatments being from 
14 to 21 days.

Micronutrients, as well as macronutrients, had their greatest demand from the middle to the end of the cycle, because in this period, the physiological activity of the plants is more intense in view of the greater mass gain (Figs. 5 and 7). The highest levels of boron, copper, iron, manganese, molybdenum and zinc were observed at 21 DAT in all treatments and in both cultures.

The absorption of micronutrients for the treatments $\mathrm{T} 1$ and $\mathrm{T} 2$, in winter and summer, perfectly accompanies the characteristic behavior of the dry mass gain of the culture. In the treatment $\mathrm{T} 3$, this absorption was lower in relation to the other treatments, evidencing that the quantities found in the wastewater may not be sufficient to meet the culture demand, but also emphasize the need for analysis and quantification of micronutrient contents in wastewater.

When evaluating and comparing the results of nutrient absorption during the different periods, it was noted that in the summer there was a greater accumulation for most of the elements in all the treatments, but mainly for T1 and T2. Only the accumulated levels of magnesium and boron for $\mathrm{T} 1$ and $\mathrm{T} 2$ were lower in the summer compared to the winter values. Martinez and Silva Filho (2004) point out that there may be differences in nutrient uptake rates for the same culture at different times of the year and, further supporting these results, Adams (1991) in a work on tomato growing in hydroponics observed that nutrient and water absorption can be twice as high in summer.

The plant growth curve, expressed by the dry mass accumulation of the crops (Figs. 5 and 7), was represented by a second-degree

Table 4

Analysis of variance of the fresh mass of the plants, electrical conductivity and $\mathrm{pH}$ of the nutrient solution according to the periods of the year (summer and winter) and different types of nutrient solution.

\begin{tabular}{llll}
\hline Variation Causes & \multicolumn{2}{l}{ Mean Square } & \\
\cline { 2 - 4 } & Fresh Mass & EC & $\mathrm{pH}$ \\
\hline Periods (P) & $124,559^{* *}$ & $0.60^{* *}$ & $0.005^{\mathrm{ns}}$ \\
Types of Nutritive Solution (S) & $602,532^{* *}$ & $22.43^{* *}$ & $33.92^{* *}$ \\
Interaction (P)*(S) & $35,135^{* *}$ & $0.17^{* *}$ & $0.31^{\mathrm{ns}}$ \\
Residue & 564 & 0.01 & 0.2 \\
CV\% & 7.94 & 38.87 & 6.23 \\
\hline
\end{tabular}

$\mathrm{CV}$ : Coefficient of variation between the results of each treatment; ${ }^{\text {ns: }}$ Not significant by F test; *, ** Significant at 0.05 and 0.01 probability respectively; EC: electrical conductivity.

polynomial equation, showing high correlation for all treatments, and greater accumulation from 14 DAT onwards. In summer, the dry mass at the end of the period was $80.5,54.32$ and $67.81 \%$ greater than during the winter cultivation for treatments $\mathrm{T} 1, \mathrm{~T} 2$ and $\mathrm{T} 3$, respectively.

Fig. 8 presents the results of the daily monitoring of $\mathrm{pH}$ and electrical conductivity of the nutrient solutions of the different treatments, in both periods. The results of 2-way ANOVA of the nutrient solution's electrical conductivity and fresh mass of the plants indicated a significant interaction between the growing seasons (winter and summer)
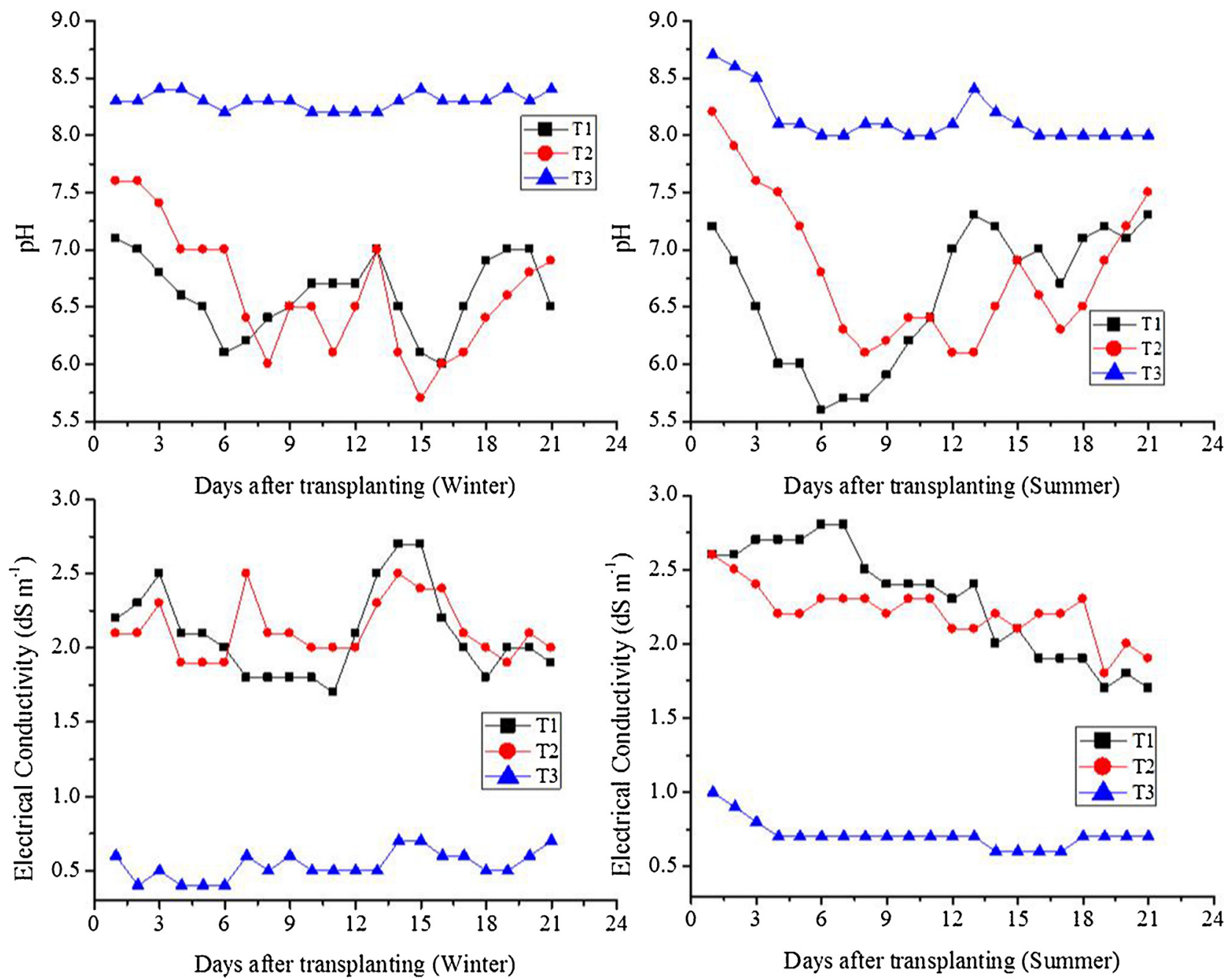

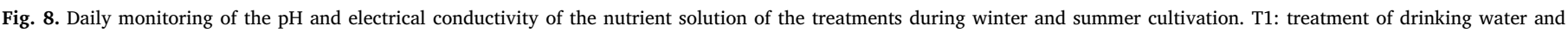
chemical fertilizers; T2: wastewater treatment and supplemented with chemical fertilizers; T3: wastewater treatment only. 
Table 5

Average values of the fresh mass of the plants, electrical conductivity and $\mathrm{pH}$ of the nutrient solution according to the periods of the year (summer and winter) and different types of nutrient solution submitted to the Tukey test.

\begin{tabular}{lllll}
\hline Variables & Factors & \multicolumn{4}{l}{ Types of Nutritive Solution } \\
\cline { 3 - 5 } & & $\mathrm{T} 1$ & $\mathrm{~T} 2$ & $\mathrm{~T} 3$ \\
\hline \multirow{2}{*}{ Fresh Mass $(\mathrm{g})$} & Winter & $464.11 \mathrm{aA}$ & $443.75 \mathrm{aA}$ & $118.60 \mathrm{bA}$ \\
& Summer & $330.68 \mathrm{aB}$ & $322.74 \mathrm{aB}$ & $113.71 \mathrm{bA}$ \\
$\mathrm{EC}\left(\mathrm{dS} \mathrm{m}^{-1}\right)$ & Winter & $2.09 \mathrm{aB}$ & $2.12 \mathrm{a}$ & $0.53 \mathrm{bB}$ \\
& Summer & $2.30 \mathrm{aA}$ & $2.21 \mathrm{a}$ & $0.71 \mathrm{bA}$ \\
$\mathrm{pH}$ & Winter & $6.60 \mathrm{~b}$ & $6.62 \mathrm{~b}$ & $8.30 \mathrm{a}$ \\
& Summer & $6.61 \mathrm{~b}$ & $6.81 \mathrm{~b}$ & $8.14 \mathrm{a}$ \\
\hline
\end{tabular}

Means followed by the same lower case letter in each line and the uppercase letter in each column do not differ at the level of 0.05 probability by the Tukey test. EC: electrical conductivity; T1: treatment of drinking water and chemical fertilizers; T2: wastewater treatment and supplemented with chemical fertilizers; T3: wastewater treatment only.

and treatments (T1-T3), according to Tables 4 and 5.

Regarding the $\mathrm{pH}$ of the nutrient solutions, there was no interaction of the factors, and only the simple effect of the treatments was found. During the experimental period, an oscillation of its values for the treatments T1 and T2 (Fig. 8) occurred, however, this variation is expected, since the nutrient solution does not have buffering capacity (Backes et al., 2004). The range considered adequate for hydroponic plant growth is 5.5-6.5 (Furlani, 1999). The average $\mathrm{pH}$ values (Table 5) were above the range considered ideal for nutrient absorption, but even in these conditions no visual symptoms of nutrient deficiency were observed for the T1 and T2 treatments. Also, according to Bugbee (2004), plants also grow in the $\mathrm{pH}$ range of 4-7, if the nutrients are not limiting. For the treatment with only wastewater, the $\mathrm{pH}$ remained stable in comparison with the other treatments, however, above the ideal.

The $\mathrm{pH}$ fluctuations in nutrient solutions are attributed to the unbalanced uptake of ions by plants (Marschner, 2012). Most of the nitrogen supplied through the nutrient solution is in the nitric form, with the anion absorption being greater than that of cations, with the occurrence of $\mathrm{pH}$ elevation. This occurs because the absorption of one mole of $\mathrm{NO}_{3}{ }^{-}$is done in co-transport with two moles of $\mathrm{H}^{+}$, while in the uptake of one mole of $\mathrm{NH}_{4}{ }^{+}$can occur the pumping of one mole of $\mathrm{H}^{+}$to the outside of the cell (Cometti et al., 2006).

The highest $\mathrm{pH}$ at the end of the summer period influenced the absorption of magnesium and boron in treatments $\mathrm{T} 1$ and $\mathrm{T} 2$, and the contents found were below the ideal range for lettuce, as proposed by Raij et al. (1997), but without presenting visual symptoms of this deficiency.

The average electrical conductivity of the $\mathrm{T} 1$ and $\mathrm{T} 2$ treatments (Fig. 8 and Table 5) was similar to that recommended for the cultivation of lettuce in hydroponics, which is $2.5 \mathrm{dS} \mathrm{m}^{-1}$ (Azad et al., 2013). Backes et al. (2004), in a study on nutrient replacement in nutrient solutions for lettuce cultivation, observed that in the treatments with higher $\mathrm{pH}$ and electrical conductivity oscillations there was a lower production of total fresh matter.

Data on the characterization of climatic conditions during the experimental period (Fig. 1) show that the mean air temperature inside the greenhouse was $29.08^{\circ} \mathrm{C} \pm 2.37$ for summer and $24.5^{\circ} \mathrm{C} \pm 2.77$ for winter. Summer is characterized by higher temperatures, greater luminosity and solar radiation, increasing the evapotranspirative demand of the culture. The monitoring of the volume of water used during each culture to prepare and replenish the nutrient solution demonstrates higher water consumption during the summer compared to winter (Table 6). In the T3 treatment due to the reduced plant growth the water consumption was much lower when compared to the other treatments.

Bugbee (2004) suggests the use of the nutrient amounts necessary for the plants diluted by the volume of water spent for the production
Table 6

Water consumption for the preparation and replacement of nutrient solutions during the experimental period.

\begin{tabular}{lll}
\hline Treatments & & Amount of water used (L) \\
\hline \multirow{2}{*}{ Summer } & T1 & 1057 \\
& T2 & 905 \\
\multirow{3}{*}{ Winter } & T3 & 585 \\
& T1 & 986 \\
& T2 & 872 \\
& T3 & 469
\end{tabular}

T1: treatment of drinking water and chemical fertilizers; T2: wastewater treatment and supplemented with chemical fertilizers; T3: wastewater treatment only.

per unit of mass, however, Cometti et al. (2006), emphasize that under tropical climate conditions with high transpiration, in which there is an absorption of a large volume of nutrient solution, it is necessary to know the transpiration of the lettuce culture in the NFT system, as well as the relation and amount of nutrients absorbed for such condition. As shown in the results of this work, there are variations in the amount of nutrients absorbed in different periods of the year, considering that the distribution pattern of treatments was uniform inside the greenhouse, as well the conditions of nutrient solution management.

Lettuce is a culture adapted to milder climate, being suitable for growing in winter (Lopes et al., 2003), when it reaches the highest values of fresh mass, as observed in this study from the interaction between cultivation periods and treatments (Tables 4 and 5) and reported in the literature (Chekli et al., 2017; Feltrin et al., 2005; Sediyama et al., 2009). Comparing values obtained for dry mass (Fig. 5 and 7) with the fresh mass of the treatments, it is noted that in winter there was a higher moisture content per plant and in summer a greater accumulation of dry mass in all treatments. The dry mass of the plant is composed of mineral elements in which $90 \%$ are carbon, hydrogen and oxygen as the remaining $10 \%$ contain all other mineral elements absorbed in the crop's environment (Epstein and Bloom, 2004). Sediyama et al. (2009) evaluate the performance of hydroponic lettuce cultivars growth at winter and summer period and observed a stem-stretching tendency of some lettuce varieties at higher temperatures, resulting in a smaller number of leaves, which happened herein in plants grown in the summer period. Additionally, the lettuce stem may have worked as a nutrient storage, contributing for a greater mineral element accumulation in the summer.

In the $\mathrm{T} 3$ treatment, the electrical conductivity remained stable, in winter and summer, with small variations, but below the ideal for culture in this system. The origin of the effluent used and the treatment process employed directly reflect this value. Nutrient levels are much lower than the nutrient content of the solutions and the proportions are also different from those used by several researchers (Martinez and Silva Filho, 2004; Furlani, 1999).

In the summer period, treatments $\mathrm{T} 1$ and $\mathrm{T} 2$ in relation to fresh mass did not differ statistically, and in winter there was also no difference (Table 5). However, the averages of these same treatments differ statistically in relation to the growing season, being higher in winter. Between winter and summer cultivation the T3 treatment did not present differences, but it was significantly different from the other treatments during the two periods.

These results confirm the negative effect of lack of nutrients on plant growth, demonstrating that wastewater without nutrient supplementation is not feasible for use in hydroponics of lettuce culture. It is also possible to conclude that although there were variations in the chemical and physical characteristics of the wastewater used in the T2 (Table 1), there was no influence on the production and the accumulation of nutrients when compared to T1.

T3 plants presented lower roots and leaves, as a consequence of reduced nutrient supply in the wastewater, therefore lower fresh mass and dry mass when compared to T1 and T2 (Table 5). It is assumed that 
there was no loss in the $\mathrm{T} 3$ because of the time that the plants were in the nursery with the conventional nutrient solution. This time with the nutrient solution may have provided an efficient absorption of nutrients at this stage during the first 14 days. In Figs. 4-7 it can be observed that up to 7 DAT in the T3 treatment, the plants had already absorbed approximately $50 \%$ of the accumulated total over the period evaluated for most nutrients.

The difference found in the fresh mass results, dry mass and the accumulated maximum of plant nutrients between the T1 and T2 treatments in the winter and summer period can be attributed to the difference in the meteorological conditions in the times when the plants were cultivated (Fig. 1). According to Feltrin et al. (2005), in the summer, which is characterized by high temperatures reaching $30^{\circ} \mathrm{C}$ during the day, plants shorten the vegetative cycle, inducing premature flowering, resulting in plants with a reduction in the total fresh mass, which can be observed in the present work. Wastewater used had no effect on this result, when comparing the performance of the T1 with the T2, because in each culture there was no significant difference between the two.

For the treatment with only wastewater, the temperature difference between the evaluated periods did not influence the results found, as opposed to the insufficient amount of nutrients, that limited the development of the plants in the two periods, resulting in small plants with symptoms of generalized nutritional deficiency and non-commercial plants.

\section{Conclusions}

Wastewater has the potential to be used as an alternative source of water for hydroponic lettuce cultivation, and there is no damage in terms of production for the culture, as long as a nutritional contribution is made, independent of the time of year. Its supplementation with fertilizers allows the increasing accumulation of nutrients, similar to the treatment of water supply with chemical fertilizers, as opposed to its use without addition of nutrients, which leads to the reduction of fresh mass and nutritional deficiencies in the plants, making them out of marketing standards.

\section{Acknowledgements}

The authors gratefully acknowledge São Paulo Research Foundation (FAPESP) and Coordination for the Improvement of Higher Education Personnel (CAPES) for the scholarship granted R.S.C. Carvalho. Financial support was provided by FAPESP (2013/14893-7 and 2013/ 13803-4) and National Council for Scientific and Technological Development (CNPq).

\section{References}

American Public Health Association (APHA), 2012. Standards Methods for the Examination of Water and Wastewater, 22nd ed. APHA, Washington, DC

Abrahão, C., Bôas, R.L.V., Bull, L.T., 2014. K: Ca: Mg ratio in nutrient solution for production of mini tomato grown in substrate. IRRIGA 19, 214-224.

Adams, P., 1991. Effects of increasing the salinity of the nutrient solution with major nutrients or sodium chloride on the yield, quality and composition of tomatoes grown in rockwool. J. Hortic. Sci. 66, 201-207.

Almuktar, S.A.A.A.N., Scholz, M., Al-Isawi, R.H.K., Sani, A., 2015. Recycling of domestic wastewater treated by vertical-flow wetlands for irrigating Chillies and Sweet Peppers. Agric. Water Manage. 149, 1-22.

Ayers, R.S., Westcot, D.W., 1999. A qualidade de água na agricultura, 2nd ed. UFPB, Campina Grande pp. 153

Azad, A.K., Ishikawa, K., Diaz-Perez, J.C., Eaton, T.E.-J., Takeda, N., 2013. Growth and development of komatsuna (Brassica rapa L. Nothovar) in NFT (nutrient film technique) system, as influenced by natural mineral. Agric. Sci. 04, 1-7.
Böhme, M., 1993. Parameters for calculating nutrient solutions for hydroponics. International Congress on Soilless Culture Vol. 8. Intenational Society for Soilless Culture, Wageningen, pp. 85-96.

Backes, F.A.A.L., Santos, O.S.S., Pilau, F.G., Bonnecarrère, R.A.G., Medeiros, S.L.P., Fagan, E.B., 2004. Nutrients replacement in nutrient solution for lettuce hydroponic cultivation. Ciência Rural 34, 1407-1414.

Boyden, B.H., Rababah, A.A., 1996. Recycling nutrients from municipal wastewater Desalination 106, 241-246.

Bugbee, B., 2004. Nutrient management in recirculating hydroponic culture. South Pacific Soilless Culture Conference-SPSCC Vol. 648, 99-112.

Chekli, L., Kim, J.E., Saliby, I., El Kim, Y., Phuntsho, S., Li, S., Ghaffour, N., Leiknes, T., Kyong Shon, H., 2017. Fertilizer drawn forward osmosis process for sustainable water reuse to grow hydroponic lettuce using commercial nutrient solution. Sep. Purif. Technol. 181, 18-28.

Cometti, N.N., Furlani, P.R., Ruiz, H.A., Fernandes Filho, E.I., 2006. IV-Soluções Nutritivas: Formulação E Aplicações.

Cuba, R.S., Carmo, J.R., Souza, C.F., Bastos, R.G., 2015. Potential of domestic sewage effluent treated as a source of water and nutrients in hydroponic lettuce. Rev Ambiente Água 10, 574-586.

dos Santos, J.D., Lopes da Silva, A.L., da Luz Costa, J., Scheidt, G.N., Novak, A.C., Sydney, E.B., Soccol, C.R., 2013. Development of a vinasse nutritive solution for hydroponics. J. Environ. Manage. 114, 8-12.

Epstein, E., Bloom, A.J., 2004. Mineral Nutrition of Plants: Principles and Perspectives. Sinauer Associates, Sunderland pp. 401.

Feltrin, A.L., Cecílio Filho, A.B., Branco, R.B.F., Barbosa, J.C., Salatiel, L.T., 2005. Yield of american lettuce cultivated in soil and hydropony during winter and summer seasons in Jaboticabal, SP. Revista Brasileira de Engenharia Agrícola e Ambiental 9, 505-509.

Furlani, P.R., 1999. Hydroponic vegetable production in Brazil. Acta Hortic. (ISHS) 481, $777-778$.

Gondim, A.R.O., Flores, M.E.P., Martinez, H.E.P., Fontes, P.C.R., Pereira, P.R.G., 2010 Electric conductivity in the production and nutrition lettuce in NFT system. Biosci. J. 26, 894-904.

Grangeiro, L.C., Costa, K.R., Medeiros, M.A., Salviano, A.M., Negreiros, M.Z., Bezerra Neto, F., Oliveira, S.L., 2006. Accumulation of nutrients by three lettuce cultivars grown under semi-arid conditions. Horticultura Brasileira 24, 190-194.

Lopes, M.C., Freier, M., Matte, J.C., Gärtner, M., Franzener, G., Nogarolli, E.L., Sevignani, A., 2003. Nutrient accumulation by lettuce cultivars under hydroponic culture in the winter. Horticultura Brasileira 21, 211-215.

Marschner, P., 2012. Mineral Nutrition of Higher Plants, 3rd ed. Academic Press, London pp. 651.

Martinez, H.E.P., Silva Filho, J.B., 2004. Introdução ao cultivo hidropônico de plantas, 2nd ed. Editora da Universidade Federal de Viçosa, Viçosa pp. 111.

Martins, C.M., Medeiros, J.F., Lopes, W.D.A.R., Braga, D.F., Amorim, L.B., 2009. Curve of absorption of nutrients in hydroponic lettuce. Revista Caatinga 22, 123-128.

Nogueira, A.R.A., Souza, G.B., 2005. Manual de laboratórios: solo, água, nutrição vegetal, nutrição animal e alimentos. Embrapa Pecuária Sudeste, São Carlos pp. 313.

Paulus, D., Paulus, E., Nava, G.A., Moura, C.A., 2012. Growth, water consumption and mineral composition of lettuce in hydroponic system with saline water. Revista Ceres 59, 110-117.

R CORE TEAM, 2015. R: A Language and Environment for Statistical Computing. R Foundation for Statistical Computing, Vienna. http://www.R-project.org/ (Accessed 10 February 18 )

Raij, B.V., Cantarella, J.A., Quaggio, J.A., Furlani, A.M.C., 1997. Boletim Técnico no 100: Recomendações De Adubação E Calagem Para O Estado De São Paulo, 2nd ed. Instituto Agronômico de Campinas, Campinas.

Rana, S., Bag, S.K., Golder, D., Mukherjee (Roy), S., Pradhan, C., Jana, B.B., 2011 Reclamation of municipal domestic wastewater by aquaponics of tomato plants. Ecol. Eng. 37, 981-988.

Resh, H.M., 1995. Cultivos hidropônicos, 4th ed. Ediciones Mund-Prensa, Madrid.

Roosta, H.R., Hamidpour, M., 2013. Mineral nutrient content of tomato plants in aquaponic and hydroponic systems: effect of foliar application of some macro and micronutrients. J. Plant Nutr. 36, 2070-2083.

Saufie, S., Estin, A., Tamin, M., Harun, A., Obong, S., Mustafa, S., 2015. Growt performance of tomato plant and genetically improved farmed tilapia in combined aquaponic systems. Asian J. Agric. Res. 9, 95-103.

Sediyama, M.A.N., Pedrosa, M.W., Salgado, L.T., Pereira, P.C., et al., 2009. Summer and winter performance of lettuce cultivars grown in a hydroponic system. Científica Jaboticabal 37, 98-106.

Soares, T.M., Silva, E.F.F., Duarte, S.N., Mélo, R.F., Jorge, C.A., Bonfim-Silva, E.M., 2007. Hydroponic lettuce production using saline waters. IRRIGA 12, 235-248.

Souza, C.F., Bastos, R.G., de Moraes Gomes, M.P., Pulschen, A.A., 2015. Efficiency of domestic wastewater treatment plant for agricultural reuse. Revista Ambiente Água 10, 587-597.

Taiz, L., Zeiger, E., 2013. Fisiologia Vegetal, 5th ed. ArtMed, Porto Alegre.

World Health Organization (WHO), 2006. Guidelines for the Safe Use of Wastewater, Excreta and Greywater. Wastewater Use in Agriculture, vol. 2 WHO, Geneva.

Yeo, K.-H., Lee, J.-H., Lee, Y.-B., 2013. Determination of optimal levels of Ca and Mg for single-stemmed roses grown in closed aeroponic system. Hortic. Environ. Biotechnol. 54, 510-518. 